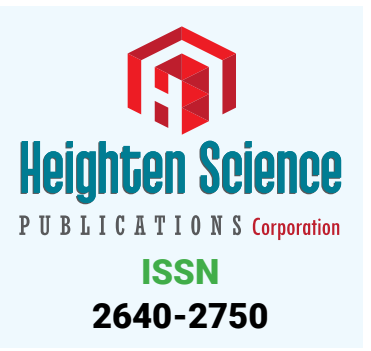

*Address for Correspondence: Dr. S Nanthakumar, Resident in Pediatrics, Department of Pediatrics Institute of Child Health \& Hospital for Children, Chennai-8, Tamil Nadu, India, Email: samnandha01@gmail.com

Submitted: 09 June 2017

Approved: 13 July 2017

Published: 14 July 2017

Copyright: @ 2017 Nanthakumar S, et al. This is an open access article distributed under the Creative Commons Attribution License, which permits unrestricted use, distribution, and reproduction in any medium, provided the original work is properly cited.

Keywords: Duodenal duplication cyst; Anemia; ChildrenPancreatitis; Cholecystitis; Children

Check for updates
Case Report

\section{Anemia due to a rare anomaly - Case Report}

\author{
S Nanthakumar ${ }^{1 \star}$, Sumathi Bavanandam² ${ }^{2}$ Nirmala Dheivamani ${ }^{3}$, \\ Natarajan $B^{4}$ and Krishna Mohan ${ }^{5}$ \\ ${ }^{1}$ Resident in Pediatrics, Department of Pediatrics, Institute of Child Health \& Hospital for \\ Children, Chennai-8, Tamil Nadu, India \\ ${ }^{2}$ Senior Assistant Professor, Department of Pediatric Gastroenterology, Institute of Child Health \\ \& Hospital for Children, Chennai-8, Tamil Nadu, India \\ ${ }^{3}$ Professor\& Head, Department of Pediatric Gastroenterology, Institute of Child Health \& \\ Hospital for Children, Chennai-8, Tamil Nadu, India \\ ${ }^{4}$ Senior Assistant professor of Radiology, Institute of Child Health \& Hospital for Children, \\ Chennai-8, Tamil Nadu, India \\ ${ }^{5}$ Professor, Department of Pediatric Surgery, Institute of Child Health \& Hospital for Children, \\ Chennai-8, Tamil Nadu, India
}

\section{ABSTACT}

Anemia due to gastrointestinal blood loss can occur due to many conditions and rarely to bowel structural anomalies. We report a 12 years old girl with anemia due to small bowel duplication cyst, posing diagnostic challenge intra operatively. Surgery offered cure without recurrence of bleeding. Common symptoms can be due to a rare surgical condition in practice.

\section{CASE REPORT}

A 12 year old female $1^{\text {st }}$ born child of non- consanguineous parents presented with easy fatigability, dyspnea on exertion of 2 weeks duration, and a history of passing one black tarry stool. There was no haematemesis, abdominal pain, vomiting. Clinical examination were unremarkable except for significant pallor with hyperdynamic circulation. Her BMI was 16.8 . Weight and height was $32 \mathrm{~kg} \& 138 \mathrm{~cm}$. Investigations showed $\mathrm{Hb} 4.7 \mathrm{gm} / \mathrm{dl}$. Total leucocyte count $9600 \mathrm{cells} / \mathrm{cmm}$, differential count: polymorphs $53 \%$, lymphocyte $37 \%$, mixed $10 \%$, PCV 16.7, platelet count 4,30,000/ $\mu \mathrm{L}$ with hypochromic microcytic anemia. Fecal occult blood test on three occasions was positive. Serum iron $10 \mu \mathrm{g} / \mathrm{dl}$, ferritin $1.9 \mathrm{ng} / \mathrm{dl}$, TIBC $474 \mu \mathrm{g} / \mathrm{dl}$. Blood sugar, renal function tests, electrolytes and liver function tests were within normal. Chest $\mathrm{X}$ ray was normal. Ultrasonography [USG] abdomen showed a cyst in the second part of duodenum. She received 3 units of packed red cell transfusion. Upper gastrointestinal endoscopy was done which showed a large rounded cystic mass without surface ulcerations in the second part of duodenum (Figure 1). Provisional diagnoses were duodenal duplication cyst, GIST and choledochocele. Barium contrast study revealed intraluminal filling defect in the second part of duodenum. Finding were confirmed by endoscopic USG which showed three layered cyst in the second part of duodenum. Technetium $99 \mathrm{M}$ pertechnetate study did not reveal any ectopic gastric mucosa. She was subjected for surgery and intra operative findings showed $3 \times 3 \mathrm{cms}$ cystic mass in the second part of duodenum on the medial wall, with an opening on the inframedial part of the cyst and on aspiration showed greenish fluid, considering the possible diagnosis of choledochocele. Marsupilisation was done and hemostasis secured.

How to cite this article: Nanthakumar S, Bavanandam S, Dheivamani N, Natarajan B, Mohan K. Anemia due to a rare anomaly - Case Report. Ann Clin Gastroenterol Hepatol. 2017; 1: 004-006. https://dx.doi.org/10.29328/journal.hcg.1001002 
Histopathology was consistent with duodenal duplication (Figure 2). 'Postoperative period was uneventful. Fecal occult blood test on three consecutive days were negative and $\mathrm{Hb}$ was $11 \mathrm{gm} / \mathrm{dl}$ on follow up.

\section{DISCUSSION}

Small bowel duplication cysts are rare congenital anomalies in children and adults. The Jejunum is the most common site (50\%) [1], followed by ileum (44\%) [2] and duodenum (2-12\%) [3]. Duodenal duplication cysts are most common in the second or third portion of the duodenum [4] as in our case and consist of submucosa, muscularis propria, a duodenal epithelial lining, and intimate attachment to the GI tract [5]. Duodenal cysts are often the cystic and non- communicating type, usually [6]. Located at the medial border of the second part of the duodenum and extending anteriorly or posteriorly Clinical presentation is variable. Children can be asymptomatic or present with abdominal pain, vomiting, intussusceptions, intestinal obstruction, pancreatitis, obstructive jaundice and gastrointestinal blood loss of varying severity due to presence of ectopic gastric mucosa $[3,7,8]$. Though our patient did not reveal any gastric mucosa on technetium labelled study, ulcerations on histology may be the cause of chronic gastrointestinal blood loss. Malignant transformation can occur as a rare complication, especially with gastric mucosa heterotopia within the duplication cyst [9]. Various diagnostic modalities can be used for workup, including barium contrast studies, USG abdomen,and upper gastrointestinal endoscopy. Contrast-enhanced CT [CECT] abdomen,Magnetic Resonance Cholangiopancreatography [MRCP] and recently Endoscopic Ultrasound[EUS] are used to give additional information of the surrounding structures to help in surgical management. On EUS, duodenal duplication cysts appear as 3-5 layer wall structures consistent with cyst of intestinal origin, and the cyst's muscularis propria can be continuous with the muscularis propria of the duodenum [10]. Controversy exists on the role of EUS guided biopsy. Surgical options include marsupilisation, resection, duodenotomy and pancreaticoduodenectomy depending upon the clinical features. Rarely, endoscopic methods may be used for treatment $[11,12]$.

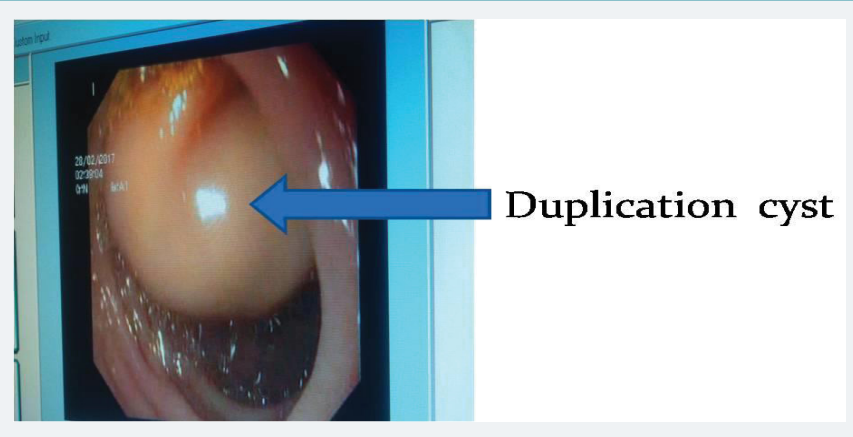

Figure 1: showing duodenal cyst on endoscopy.

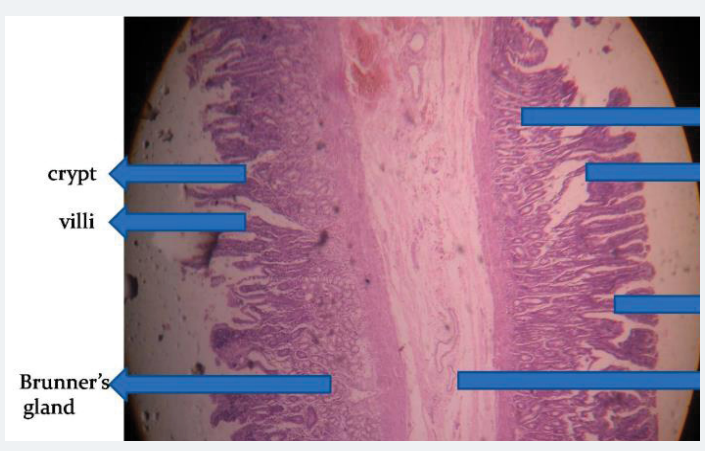

Figure 2: showing histopathology of cyst. 


\section{REFERENCES}

1. Tamvakopoulos GS, Sams V, Preston P, Stebbings WS. Iron-deficiency anaemia caused by an enterolith-filled jejunal duplication cyst. Ann R Coll Surg Engl. 2004; 86: 49-51. Ref.: https://goo.gl/ZPx91p

2. Al-Sarem SA, Al-Shawi JS. Ileal duplication in adults. Saudi Med J. 2007; 28: 1734-1736. Ref.: https://goo.gl/5FKPvz

3. Chen JJ, Lee HC, Yeung CY, Chan WT, Jiang CB, et al. Meta-analysis: The clinical features of the duodenal duplication cyst. J Pediatr Surg. 2010; 45: 1598-1606. Ref.: https://goo.gl/umsDtu

4. Ko SY, Ko SH, Ha S, Kim MS, Shin HM, et al. A case of a duodenal duplication cyst presenting as melena. World J Gastroenterol. 2013; 19: 6490-6493. Ref.: https://goo.gl/mc9AgW

5. GROSS RE, HOLCOMB GW Jr, FARBER S. Farber S. Duplications of the alimentary tract. Pediatrics. 1952; 9: 448468. Ref.: https://goo.gl/bKUaJr

6. Merrot T, Anastasescu R, Pankevych T, Tercier S, Garcia S, et al. Duodenal duplications. Clinical characteristics, embryological hypotheses, histological findings, treatment. Eur J Pediatr Surg. 2006; 16: 18-23. Ref.: https://goo.gl/dgA3Mp

7. Lad RJ, Fitzgerald P, Jacobson K. An unusual cause of recurrent pancreatitis: Duodenal duplication cyst. Can J Gastroenterol. 2000; 14: 341-345. Ref.: https://goo.gl/qYikoZ

8. Rubin RB, Saltzman JR, Zawacki JK, Khan A, Swanson R. Duodenal duplication cyst with massive gastrointestinal bleeding. J Clin Gastroenterol. 1995; 21: 72-74. Ref.: https://goo.gl/36qSPU

9. Johnson JA, Poole GV. Ileal duplications in adults. Presentation and treatment. Arch Surg. 1994; 129: 659-661. Ref.: https://goo.gl/tLcrfg

10. Guibaud L, Fouque $P$, Genin G, Valette PJ, Frering V, et al. Case report. CT and ultrasound of gastric and duodenal duplications. J Comput Assist Tomogr. 1996; 20: 382-385. Ref.: https://goo.gl/6mZTgZ

11. Ko SY, Ko SH, Ha S, Kim MS, Shin HM, et al. A case of a duodenal duplication cyst presenting as melena. World J Gastroenterol. 2013; 19: 6490-6493. Ref.: https://goo.gl/1yL1Tk

12. Antaki F, Tringali A, Deprez P, Kwan V, Costamagna G, et al. A case series of symptomatic intraluminal duodenal duplication cysts: Presentation, endoscopic therapy, and long-term outcome (with video). Gastrointest Endosc. 2008; 67: 163-168. Ref.: https://goo.gl/fa1K2R 